\title{
Significance Testing at Preshistoric Archeological Site 41RK195, Rusk County, Texas
}

\author{
Glenn T. Goode \\ Sterling Hays \\ Paul Maslyk \\ Christine G. Ward \\ Jesus Gonzalez
}

Follow this and additional works at: https://scholarworks.sfasu.edu/ita

Part of the American Material Culture Commons, Archaeological Anthropology Commons, Environmental Studies Commons, Other American Studies Commons, Other Arts and Humanities Commons, Other History of Art, Architecture, and Archaeology Commons, and the United States History Commons

Tell us how this article helped you.

This Article is brought to you for free and open access by the Center for Regional Heritage Research at SFA ScholarWorks. It has been accepted for inclusion in Index of Texas Archaeology: Open Access Gray Literature from the Lone Star State by an authorized editor of SFA ScholarWorks. For more information, please contact cdsscholarworks@sfasu.edu. 


\section{Significance Testing at Preshistoric Archeological Site 41RK195, Rusk County, Texas}

\section{Licensing Statement}

This is a work produced for the Texas Department of Transportation (TxDOT) by the report producer. TxDOT and the report producer jointly own all rights, title, and interest in and to all intellectual property developed under TXDOT's contract with the report producer. The report may be cited and brief passages from this publication may be reproduced without permission provided that credit is given to both TXDOT and the report producer. Permission to reprint an entire chapter, section, figures or tables must be obtained in advance from either the Supervisor of the Archeological Studies Branch, Environmental Affairs Division, Texas Department of Transportation, 125 East 11th Street, Austin, Texas, 78701 or from the report producer. 


\section{SignificanceTesting at Prehistoric Archeological Site 41RK195, Rusk County, Texas}

By

Glenn T. Goode, Sterling Hays, Paul Maslyk,

Christine G. Ward and Jesus Gonzales

1997

\section{Archeology Studies Program Cultural Resource Management Section Environmental Affairs Division Texas Department of Transportation}




\section{Table of Contents}

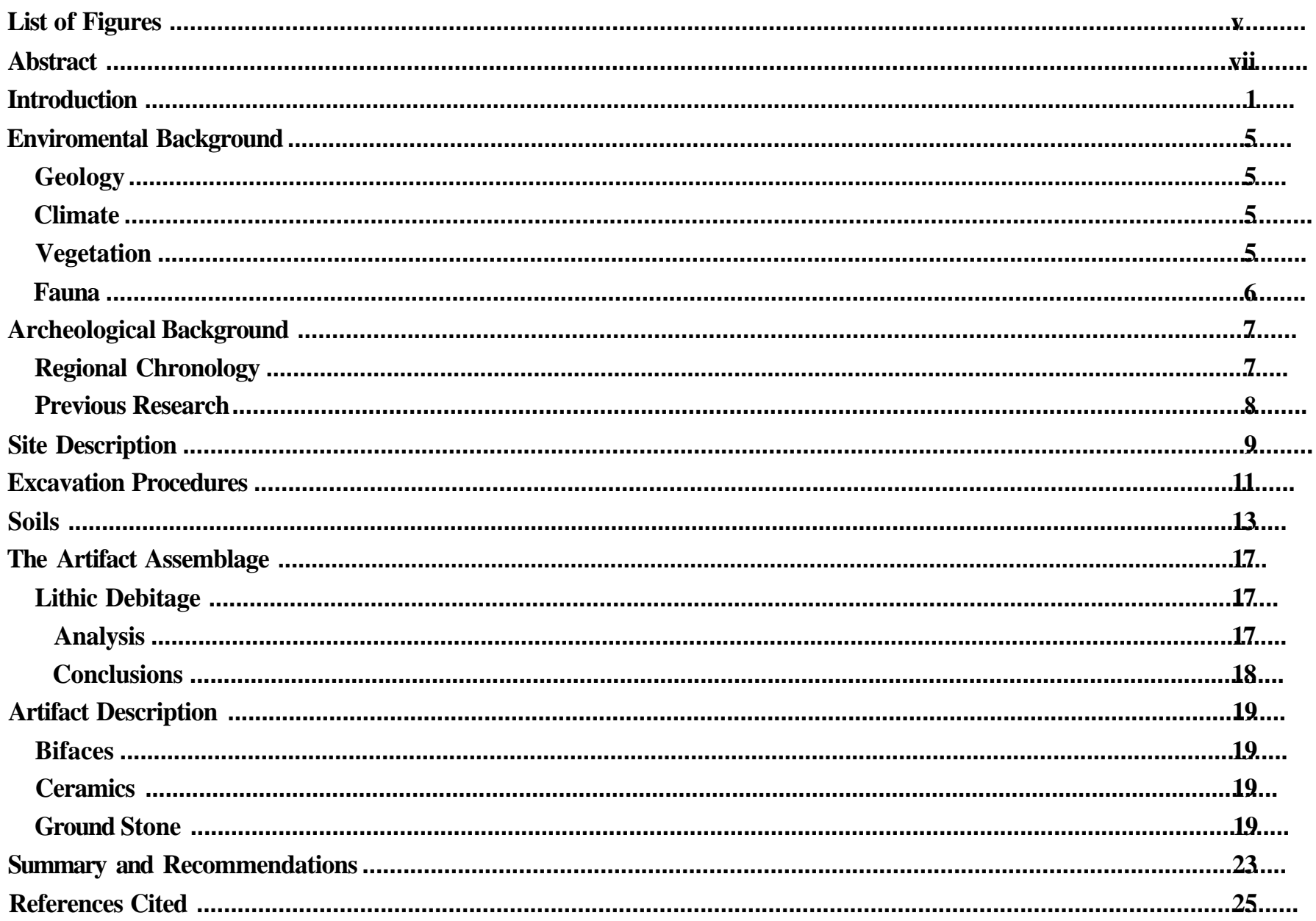




\section{LiST OF Figures}

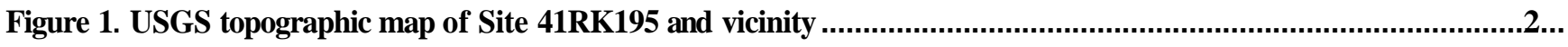

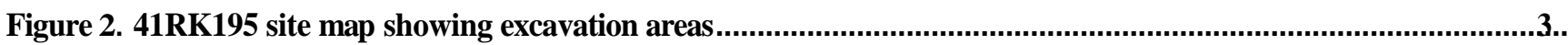

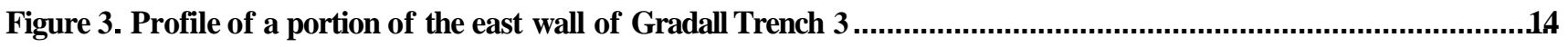

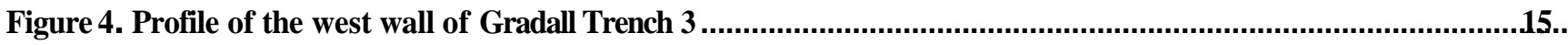

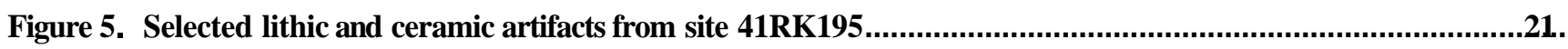




\begin{abstract}
In May 1994, the Texas Department of Transportation (TxDOT) conducted extensive test excavations at archeological site 41RK195. Located in the path of proposed Loop 571 around Henderson, the site had already been seriously impacted by a sand quarrying operation. Lying atop a large hill near the confluence of Bromley Creek and Flanigan Branch, site 41RK195, now almost totally destroyed, is believed to have been a major site of the region. The small number of artifacts found, in addition to a few seen in private collections, indicates a long history of human habitation for this multicomponent site, including occupation of the Paleoindian, Archaic and Caddoan periods. Any cultural features that may have survived into the historic era were destroyed by the sand quarrying activities.
\end{abstract}




\section{INTRODUCTION}

During the month of May 1994, archeologists from the Texas Department of Transportation (TxDOT) conducted testing of 41RK195 in Rusk County, Texas (Fig. 1). The test excavations were conducted to determine the significance of the site in compliance with the National Historic Preservation Act of 1966 prior to construction of Farm-to-Market Road (FM ) 571, the Henderson Loop.

41RK195 was discovered in March 1987 by TxDOT archeologist Glenn Goode during the cultural resources survey for the FM 571 project. At that time, it was observed that a large portion of the hill containing the site has been removed by a sand quarrying operation. The project was subsequently resurveyed by TxDOT archeologists in November 1993. During the latter survey it was found that since its discovery site 41RK195 had been further impacted by borrow activity to the extent that a great majority of the site had been destroyed. The borrow activity removed from one to eight meters of sand across the site. Consequently, it is estimated that approximately 90 to 95 percent of the cultural deposit was also removed from the site.

Additional disturbance occurred along the eastern limits of 41RK195 by the placement of three underground pipelines within an approximately $15-\mathrm{m}$ wide comdor. Despite these disturbances, a projectile point and lithic debitage were found on the surface in 1993; therefore, it was determined that significance testing of the site was still warranted.

Test excavations at the site revealed that, within the proposed right of way, only a small fraction of the site remains intact and contains very sparse cultural remains. However, judging by the small amount of cultural material found in undisturbed context (up to $1.5 \mathrm{~m}$ in depth), it is believed that even more deeply buried deposits existed in some places. Also, based on findings outside the right of way and on diagnostic artifacts in local collections, it is clear that in places, the cultural deposit was much more substantial and diverse at one time.

Site 41RK195 was tested in accordance with 36CFR, Part 800, and the Memorandum of Understanding between TxDOT and the Texas Antiquities Committee (TAC). The investigations were supervised by Glenn T. Goode of TxDOT's Environmental Affairs Division (ENV). Other members of ENV who assisted in the field work were Jesus Gonzalez, Sterling H. Hays, Paul Maslyk, and Christine G. Ward. A number of people from TxDOT's Tyler District, including John Ash, Robert Hall, Barry Scarborough, Jay Tullos, and Norman Williams, contributed significantly to the completion of this project. 
This Page Redacted Per THC Policy 


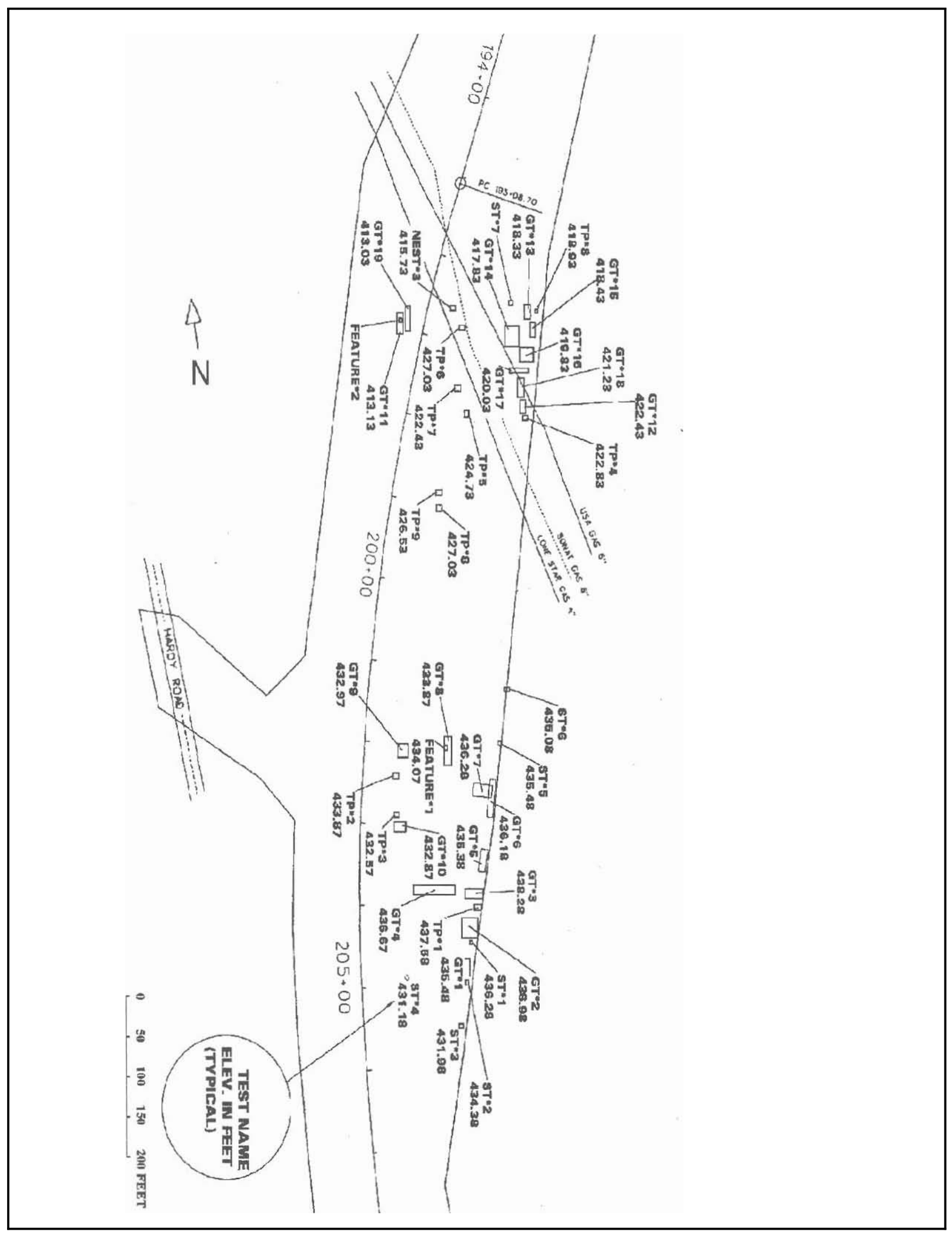

Figure 2. 41R K 195 site map showing excavation areas. 


\section{EnViromental BaCkground}

Site 41RK195 is located on the southwest outskirts of the town of Henderson, in Rusk County in eastern Texas. According to Fenneman (1938), this area falls within the West Gulf Coastal Plain, an arbitrarily defined section of the Coastal Plain physiographic province that begins west of the Mississippian Alluvial Plain and continues well into northeast Mexico. The West Gulf Coastal Plain area is similar to ancestral marine and deltaic processes of the nearby Gulf of Mexico (Sellards et al. 1932). Here, sedimentary bedrock formations of limestone and sandstone laid down during the Cretaceous period parallel the margins of the ancient receding coastline, with the more resistant strata outcropping as cuestas or escarpments across the generally southern dip of the present land surface (Perttula et al. 1986; Fisher 1965).

In the upper end of the West Gulf Coastal Plain, the ground surface is gently rolling, with streams lying in shallow valleys, most of which run to the east because of the cuestas (Story, et al, 1990). Otherwise, the land surface in the project area is rolling to hilly with occasional flat areas along the interstream divides. The escarpments mark zones where different sets of minerals and rock resources can be found (Perttula et al. 1986), where soil types change (Godfrey et al. 1973), and where stream valley configurations differ (Fisher 1965).

\section{GEOLOGY}

Site 41RK195 is just within the Neches River Basin, an area structurally dominated by the Sabine Uplift. The Uplift also coincides with the transition zone between the ancient alluvial and deltaic plains. The dominant geologic unit in this area is the Wilcox group, mostly silty and sandy clay with local beds of clay, lignite, silt, and quartz sand. Calcareous siltstone and ironstone concretions (hematite) are common (Barnes 1965). Other formations in the area are the Reklaw Formation, composed of a silty muscovitic carbonaceous clay, with iron nodules and marine fossils present. Lower levels of this formation consist of fine to very fine grained quartz sand. The other main formation in the area is the Carrizo Sand Formation. The upper part consists of very fine sand, silt, clayey silt, and silty clay; the lower part is composed of fine to medium grained quartz sand. The high sand content of the Wilcox group produces a fragile, easily disrupted environment for cultural resources. This, combined with erosion, can completely alter artifact locations.

Soils at the site belong in the Lilbert-Darco
Association. These are gently sloping to moderately steep soils that are moderately permeable. Lilbert soils have a loamy fine sand surface layer 20 to $40 \mathrm{in}$. ( 0.5 to $1.0 \mathrm{~m}$ ) thick. The subsoil is a yellowish brown sandy clay loam. Darco soils have a loamy fine surface layer more than 40 in. $(1.0 \mathrm{~m})$ thick, with a subsoil composed of a strong brown sandy clay loam. Darco soils are found on gently sloping to strongly sloping broad ridges and strongly sloping to moderately steep sideslopes above drainageways, while Lilbert soils are found on gently sloping to strongly sloping broad convex interstream divides.

\section{Climate}

Rusk County falls within Carr's (1967) East Texas climatic division, characterized by a mild climate and mean annual temperatures of $66.4^{\circ} \mathrm{F}$. Average rainfall is between 44 and 48 inches (112 to $122 \mathrm{~cm}$ ), with dual peaks in May and December; minimum precipitation occurs in August. This pattern results in a winter surplus-summerdeficit of water (Arbingast et al. 1973). Mean annual evaporation for the county is 10 inches (25 $\mathrm{cm}$ ), a factor that contributes significantly to the summer water deficit (Jackson 1982).

\section{VEGETATION}

Climate, water, and soils all affect the vegetation in an area. Site 41RK195 is located in Gould's (1975) Texas Vegetational Region 1, the Pineywoods. This region is the south-western extremity of the pinehardwood forests of the southeastern United States. Two basic associations of woody plant species occur in the region: upland pine-oak and bottomland hardwood. Changes in the vegetation between these two are distinct. Streams that are effluent most of the year are within the bottomlands division, while those that are dry for lengthy periods are within the uplands division (Jackson 1982). The site falls within the former division (bottomlands), though most of the vegetation in the area has been cleared and soil removed. Hardwoods are the dominant species, with oak, chestnut, sycamore, and hickory most prevalent. A second story is composed mostly of red maple, American holly, American hornbeam, and magnolia. The shrub understory includes waxmyale, dogwood, buttonbush, arrowwood, leatherwood, American elder, snowbell, and poison sumac (Jackson 1982). Cottonwood is also present throughout the 
bottomlands. In places, poison ivy, grape, supplejack, and greenbriar form dense thickets (Holm 1975). Nonnative plants such as crepe myrtle and Babylon weeping willow would suggest historic occupations nearby.

Climax grasses in the Pineywoods region include indiangrass, little bluestem, red love grass, sea oats, and switchgrass. Secondary growth, in areas where land clearing has removed the forest, includes greenbriar, smutgrass, western ragweed, yankeeweed, and yaupon (Gould 1969). The nut-bearing deciduous trees were probably more numerous and assumed major importance in the native economies (Keller 1974).

\section{FAUNA}

The site falls within Blair's (1950) Austroriparian biotic province, which includes the Texas Gulf Coastal Plain. The vertebrate fauna of this area of Texas is, with few exceptions, typical of the fauna throughout the entire Austroriparian Province. Blair notes at least 47 species of mammals occumng in the province in Texas, or having occurred there in recent times. Small mammals include opossum, raccoon, eastern fox squirrel, eastern gray squirrel, southern flying squirrel, plains pocket gopher, mole, fulvous harvest mouse, whitefooted mouse, rice rat, hispid cotton rat, cotton rat, eastern cottontail, and swamp rabbit. Larger mammals within the area include bobcat, coyote, red fox, gray fox, long tail weasel, both spotted and striped skunk, and the red wolf (Burt and Grossenheider 1976; Davis 1970). The presence of gophers and other burrowing animals is important from an archeological perspective as this, combined with the sandy soil, could affect the stratigraphy within an archeological site.

In addition to the variety of mammals that would have been available to the prehistoricinhabitants, an array of amphibian and reptile species would have added a considerable number of resources to exploit. Representative species include the western box turtle, leopard frog, green frog, bullfrog, eastern fence lizard, six-lined racerunner, rough green snake, common water snake, tiger salamander, and Woodhouse's toad (Jackson 1982; Stebbins 1966). With 13 species identified, the urodele fauna (amphibians with tails throughout their life) of the Austroriparian have the most species of any other province in Texas (Blair 1950).

Archeological evidence also suggests an even larger variety of fauna available to a prehistoric and historic Native American population. House (1978) notes that the bones of bison, puma, black bear, and lynx have been recovered from archeological sites within the province, despite the acidic nature of the soils affecting the preservation of faunal remains in east Texas. 


\section{Archeological Background}

\section{Regional Chronology}

Archeologists have long been trying to organize the 11,000-year time span of history and prehistory into some type of chronological framework. The framework developed for East Texas contains four main periods: the Paleoindian (ca. 11,000-6000 B.C.); the Archaic (6000200 B.C.), which is divided into Early, Middle, and Late; the Woodland or Early Ceramic (200 B.C.-A.D. 800); and the Caddoan (A.D. 800-1700), which is divided into Early Caddoan (A.D. 800-1200, subdivided into shorter periods called Formative [A.D. 800-1000] and Early [A.D. 1000-1200] by Story, et al. [1990]), Middle Caddoan (A.D. 1200-1400), and Late Caddoan (A.D. 1400-1700).

According to Davis (1970) and Story, et al. (1990), artifacts dating to the Paleoindian Period (ca. 10,0006000 B.C.) are found throughout East Texas, but none have yet been recovered in satisfactory stratigraphic context or in sufficient quantity for any meaningful analysis. Paleoindian materials are often found associated with the megafauna used for subsistence, but this relationship has not been adequately demonstrated in East Texas. Artifacts from this time period reflect the specialized subsistence and reliance on megafauna, and are evidenced by Clovis, Folsom, Plainview, Dalton, San Patrice, and Golondrina dart points, among others.

The Archaic Period (6000-200 B.C.) is only slightly better known than the Paleoindian Period for this area. Reasons for this include lack of stratigraphy at sites and poor preservation of organic materials (bone, shell, and charcoal) due to either the high acidity of East Texas soils or the occupational debris being exposed on stable land surfaces. This lack of organic materials creates gaps in the archeological information that cultural materials would otherwise leave, such as subsistence data and radiocarbon dates. Another factor contributing to the limited information could be the fact that most of the projects conducted in the area have been related to salvage archeology projects which would, by nature, impose constraints on research.

Because most of the organic material was not preserved in Archaic Period sites, the predominant remains to be analyzed in sites of this age are stone tools and the debitage left when these objects were created. Compared to the stone tools of Paleoindian times, some Archaic specimens tend to be crudely fashioned and more often made from local materials. In addition, some are more area-specific than the earlier Paleoindian style points. This could indicate an increased population density and a reduction in the size of the area exploited by Archaic groups (Story, et al., 1990).

New technologies were also introduced during the Archaic, including stone-lined hearths, baking pits, and milling stones, which suggest a heavier exploitation of plant material. Archaic sites are also marked by larger accumulations of materials, and cemeteries appear near the end of the period. Past research has shown numerous artifactual differences for the Archaic in East Texas (Davis and Davis 1960; Tunnel1 1961; Webb 1960). According to Jackson (1982, p. 12):

a series of areally delimiting terms have been applied to cope with the problem, spawning in turn more diversions as further artifact assemblage differences were defined.

Examples of this are the Red River Aspect (Davis and Davis 1960), the East Texas Aspect (Suhm et al. 1954), and the La Harpe Aspect (Johnson 1962), the latter being further divided into North, Central, and Southern divisions. All are applicable to the East Texas Archaic within their authors' specified geographical settings. Story, et al. (1990) has indicated that the latter part of the Archaic (after about 500 B.C.) is better known than the earlier periods, and that discrete late Archaic components are better documented in the middle Brazos and upper- to middle-Trinity basins than in other areas in this region. Significant areal variations are expressed as "four regional sequences of selected dart point styles and a few other formal artifacts" (Story, et al., 1990:213214). These regional sequences are expressed as: 1) eastcentral Texas, 2) north-central Texas/south-central Oklahoma, 3) southeast Oklahoma/southwest A rkansas/ northeast Texas, and 4) southeast Texas (Story, et al., 1990).

Early Archaic (ca. 6000-4000 B.C.) diagnostic dart points include Wells, Calf Creek, Johnson, and possibly Morrill, while Middle Archaic (ca. 4000-2000 B.C.) diagnostics include Bulverde, Carrollton, Trinity, and Yarbrough, and possibly other forms such as Dawson, Lone Oak, and Palmillas. The Late Archaic (ca. 2000200 B.C.) is represented by Yarbrough, Gary, Kent, and possibly side-notched forms such as Ellis and Edgewood dart points (Thurmond 1985).

The Early Ceramic or Woodland Period (200 B.C.A.D. 800) represents a time when pottery and the bow and arrow were introduced to the region. The presence of grinding stones, projectile points, and ceramics indicates a subsistence based on both plant processing 
and hunting, though it appears that plant foods were more heavily relied on than in earlier times. Evidence such as substantial midden deposits indicate that group size was increasing, sites were occupied longer (increased sedentism), and the beginnings of status differentiationis seen based on the introduction of burial mounds. Gary dart points, as well as expanding stem arrow points, and grog-tempered and sandy-paste ceramics, are indicative of this time period, which is referred to by Story, et al. (1990) as the Mossy Grove Tradition.

Caddoan (A.D. 800-1700)- Archeologists have distinctly defined this time period in East Texas in several regional variations with a number of cultural traits that developed during this time. The Caddoan period is characterized by the continued use of the bow and arrow and pottery making, with the addition of a reliance on cultigens, more prolonged stays at specific locations (sedentary or semi-sedentary settlements), and attendant social and ritual elaborations (Story, et al., 1990). Once again, there were regional variations; ceramic types and arrowpoint styles occur at different times in the four regions, causing some difficulty in creating a standard chronology. Overall, however, the chronology is divided into the Formative Caddoan (A.D. 800-1000), Early Caddoan (A.D. 1000-1200), Middle Caddoan (A.D. 1200-1400), and the Late Caddoan (A.D. 1400-1600).

\section{Previous Research}

As mentioned earlier, much of the archeological work conducted in East Texas has resulted from contract work to construct reservoirs and conduct mining activities. In the 1930s and 1940s, J.E. Pearce and A.T. Jackson, working for the University of Texas, recorded and tested numerous sites in East Texas. During this same era, Goldschmidt (1935) prepared a synthesis of archeological sites in Titus County and their relationship to sites in East Texas, through which an early cultural chronology was developed for the area. A later catalog, compiled by J. Hughes (1948), shows a listing of 26 sites for Rusk County (Espey, Huston and Associates 1990).

In 1946, the Inter-agency Archeological Salvage Program was established, along with the initiation of the River Basin Surveys Program in the late 1940s, to conduct numerous investigations in northeast Texas (Davis and Davis 1960). It was at this point that largescale reservoir surveys began. Sites recorded since that time represent the full temporal spectrum of prehistoric occupation (Skinner 1971). In nearby Harrison County, the Resch site, a multicomponent Archaic-Caddoan period site, was excavated in the late 1960s. In the 1970s, the Texas Archeological Survey (TAS) conducted archeological surveys in response to mining activity, recording 41 sites in the Lake Martin area of Rusk and Panola counties (McDonald 1972). Five of these in Rusk County were tested; one was a multicomponent site containing artifacts dating to the Late Archaic and Late Caddoan periods, three dated to the Late Caddoan, and one dated to the contact period (Clark and Ivey 1974).

Several large sites have been excavated in recent years, providing information on more recent occupations. For example, the George C. Davis site and the HudnallPirtle site have both been extensively tested and reported. The George C. Davis site is reported to date to the Early to Middle Caddoan Periods (Story and Valastro 1977) and according to Story, et al. (1990), could have been colonized by groups from the Hudnall-Pirtle site. Listed in the National Register of Historic Places (NRHP), the Hudnall-Pirtle site (41RK4) is an Early Ceramic to Early Caddoan period civic-ceremonial mound center located in the Middle Sabine River Basin in northeast Rusk County.

Recent work in Rusk County by Espey, Huston and Associates (Cruse 1994) has revealed a multi-component site--41RK222--dating to the Late Archaic, Early Ceramic, and Caddoan periods, as evidenced by early sand-tempered pottery, Friley and Alba points, small Gary and other dart points, and small burned-rock features. They also excavated site 41RK214, the Oak Hill Village Site, which is a Middle Caddoan village with many house patterns and other features such as trash pits and smudge pits (Cruse 1994). 


\section{Site Description}

Site 41RK195 is located in central Rusk County approximately 1.2 miles west of the city of Henderson. The site lies $250 \mathrm{~m}$ south of FM 13 (West Main Street), 125 m east of Hardy Road, and 125 m south and west of Bromley Creek, $200 \mathrm{~m}$ downstream from its confluence with Flanigan Branch. Very little remains of the site or of the large hill upon which it was located. A major portion of the hill has been removed by sand quarrying, with the archeological site taken along with the sand.

Today, only a portion of the hill remains, extending along a north-south axis near the proposed right of way for a distance of about $400 \mathrm{~m}$. With the apex missing, the remaining higher portions of the hill are free of woody vegetation, having been cultivated until recent years (the hill's apex and much more was under cultivation in 1987 when the site was recorded). A growth of young pine, sassafras, and oak begins a short distance to the east, approaching the fenceline of the old field. Beyond the fence begins a gradual dip of the hillside toward Bromley Creek and a dense growth of woody vegetation that includes pine, oak, hickory, cottonwood, and sassafras. In contrast, the northern slope of the hill is much steeper and is covered as much with vines as with woody vegetation. The ground surface here drops rapidly to the narrow floodplain of Bromley Creek.

In its original condition, the hill stood at least $12 \mathrm{~m}$ above the surrounding terrain. According to the previous landowner, who still owns a portion of the hill, the hill extended almost to Hardy Road on the west side; therefore, along an east-west axis, the hill's original diameter might have approached that of the north-south axis, making the hill more or less circular.

What remains of the hill at the north end is about
150 m east of Hardy Road, appearing in places as a bluff of $5 \mathrm{~m}$ height at the quarry margin. At such places, perhaps 8-10 $\mathrm{m}$ of sand have been removed. In other places, according to the landowner, anywhere from 1-4 m were removed. In the areas where less sand was taken, it was still enough to remove evidence of the cultural deposits. The southern slope of the hill, about $100 \mathrm{~m}$ long and still showing the furrows of cultivation, is intact, but no cultural deposits were found.

Other disturbances in the form of gas pipelines (Fig. 2) cut through the northeastern sector of the hill. There are three of these within a $15-\mathrm{m}$ wide comdor which the excavations avoided (contrary to their alleged locations in Fig. 2). In 1987, at least one of these pipelines had been exposed by deep erosional cuts, but the surface to the east was intact. This is not the case today, as the upper 1.0-1.5 $\mathrm{m}$ of sand have been removed. Along the pipeline corridor, the erosional cuts have been filled in, with the surrounding area reshaped and lowered.

The artifacts by which the site was recognized in 1987 came from the northern end of the site, some from the pipeline corridor and some just outside the corridor. Although an arrowpoint fragment and two small ceramic sherds were found, the overall sample was small. This led to speculation that this northern part of the site, a good distance downhill from the hill's apex, would not be especially productive. During the original survey even fewer artifacts were seen across the apex, but there had not been as much disturbance of the archeological deposits at that higher elevation. Based mainly on artifacts found outside (east of) the right of way, the higher portion of the hill does appear to have been the most productive part of the site. 


\section{Excavation Procedures}

When site 41RK195 was discovered in 1987, the hill upon which it is located had been a sand quarry for more than 10 years. Since 1987, much more of the hill (including the highest point) has been removed, to the extent that the site was almost unrecognizable and the hill's original condition hard to imagine without input from the landowner. Even though it was obvious that the greater portion of the hill had been removed (see Fig. 2), its large size ( $400 \mathrm{~m}$ across), the unknown condition of the remaining deposit, and the potential for significant cultural resources demanded a close look at what remained.

To accomplish this goal, a brief surface collection was done, then 44 test excavations of various kinds and sizes were placed between centerline stations 196 and 206 (see Fig. 2). The surface collection was brief because it was soon obvious that most of the cultural deposit had been removed by sand quarrying and no concentrations of artifacts were seen anywhere in what remained. The greater number of surface artifacts was seen in the central portion of the site, but east of and outside the proposed right of way. The surface collection, then, was not useful in guiding the placement of the test holes, the greater number of which were Gradall excavations (24) that varied considerably in size and depth.

Of the 24 Gradall Trenches (GT), 19 were standard horizontal cuts into the ground surface, ranging from trenches of $1.5 \mathrm{~m}$ width and 4-10 m length to block excavations as large as 5 by $6 \mathrm{~m}$. The greatest depth of a trench was $2.5 \mathrm{~m}$ and the shallow parts of some block excavations were $0.5 \mathrm{~m}$, with many of both between 1 and $2 \mathrm{~m}$ deep. The remaining five Gradall excavations were vertical cuts along the west face of the quarry wall. These tests were $1.5 \mathrm{~m}$ wide (one blade width), $0.5 \mathrm{~m}$ deep into the face, and $3 \mathrm{~m}$ in depth, cut from the existing ground surface almost to the quarry floor. It was along this wall of the quarry that a local man, Randy Hudgins, claims to have found the bases of two late Paleoindian dart points protruding from the sand face about $0.6 \mathrm{~m}$ below the existing surface.

The Gradall was used to quickly reveal the character of the deposit and expose the cultural remains, particularly any features. Several disturbances of possible cultural origin were carefully investigated, but were found to be of natural origin, with one exception. This anomaly apparently was created by tree removal along the northern edge of the quarry. The circumstances of these findings, including the absence of artifacts, did not seem to warrant the screening of any Gradall backdirt. No artifacts were observed in any of the Gradall excavations.

The artifact sample recovered through excavation came from the remaining 20 test pits which were dug by hand; all of this matrix was screened through $1 / 4$-inch hardware cloth. Of these test pits (TP), 11 were $1 \times 1 \mathrm{~m}$ and nine were $0.5 \times 0.5 \mathrm{~m}$ in size. Most of the $1 \times 1 \mathrm{~m}$ units were placed in areas where the likelihood of finding undisturbed cultural deposits seemed greatest, or adjacent to disturbances of possible cultural origin (two instances). These pits ranged in depth from $40 \mathrm{~cm}$ to 170 $\mathrm{cm}$, with most averaging 80 to $100 \mathrm{~cm}$. Only one of these, TP 1 (see Fig. 2), was located in an area undistrubed by sand quarrying. This unit was at the south end of the hill and, judging by the absence of artifacts, beyond the southern margin of the site (which is farthest from the creek).

The greatest amount of cultural material (but a very meager return) was found in the north-central section of the site, in TP 5 and TP 7, and in a less deeply quarried $(1 \mathrm{~m})$ area east of the right of way. Based on conversations with the landowner and on projections of the hill's original contour, it is believed that relatively little of the sandy deposit was removed from the immediate vicinity of TP 5 and TP 7. Therefore, these provide the most complete view of site stratigraphy (to a depth of $1.7 \mathrm{~m}$ ) and artifact distribution remaining at the site. However, these units are relatively near the site's northern margin, far from the hill's apex to the south, and, for the site as a whole, cannot be considered representative on either count.

From the few dart points seen in private collections and from artifacts found on the surface, it appears that other areas of the site, especially the central section, may have been significantly more productive at one time than the immediate vicinity of TP 5 and TP 7. 


\section{SoILS}

The original ground surface of 41RK195 has been heavily disturbed by the previous landowner. As recently as the 1980s, the central, southern, and eastern areas of the site were under cultivation while the rest was used as a sand source. Additionally, the majority of the site was impacted by the removal of up to four meters of soil in the south-central area and by the removal of approximately eight meters of soil in the central area. The Henderson, Tex. 7.5' 1973 USGS topographic map shows the area occupied by 41RK195 to have been a hill with an altitude somewhat greater than 440 feet $(134 \mathrm{~m})$ above mean sea level in the center, tapering to an altitude of 420 feet $(128 \mathrm{~m})$ above mean sea level around the perimeter. During these testing efforts, it was established that the highest preserved elevation at the center of the site was 436.28 feet $(132.9 \mathrm{~m})$ above mean sea level in the center, tapering to an altitude of 413.13 feet (125.8 $\mathrm{m})$ in the north and 431.18 feet $(131.3 \mathrm{~m})$ above mean sea level in the south. Aerial photographs from the 1940s indicate that the area was heavily forested. The previous landowner reported to the excavators that he began removing soil from the area in the 1970s and continued to do so until 1993. It should be stated that the following stratigraphy observed at 41RK195 is relative to the lack of the uppermost soil zones that were removed previous to testing the site.

The ground surface in the southern area of the site near the location of centerline station 204+00 was covered in dense native grasses. Although the majority of the site was severely disturbed by the removal of soil for borrow material, the extreme southern area remains mostly undisturbed. The natural stratigraphy of this area of the site was observed in a series of Gradall trenches excavated along the centerline of the proposed roadway and was best represented in Trench 3. Trench 3 was an east-west oriented trench $10 \mathrm{~m}$ in length and $5 \mathrm{~m}$ width, which reached a depth of $1.65 \mathrm{~m}$ below the present ground surface (Fig. 3).

The stratigraphy within Trench 3 consisted of four distinct natural soil zones and two overlying, artificiallydeposited zones. The uppermost zone was a $15-\mathrm{cm}$ thick deposit of dark brownish-yellow sandy loam (Munsell 10 YR 4/4 brownish-yellow dry), averaging $15 \mathrm{~cm}$ in thickness, that had a high concentration of root activity. There is a noticeable lack of organic humates in the upper zone. Underlying the upper deposit was a $2-\mathrm{cm}$ thick lens of light gray sand (Munsell 10 YR 7/2 graybrown). This thin gray band, which ranged from 8 to 20 $\mathrm{cm}$ below the ground surface, marked the division between disturbed and undisturbed stratigraphy in this area. The third soil zone consisted of a $15-$ to $50-\mathrm{cm}$ thick deposit of light gray sand (Munsell 10 YR 7/2 light gray-moist) beginning between 10 and $50 \mathrm{~cm}$ below the ground surface. The fourth soil zone consisted of a 25to 45-cm thick deposit of brown sand (Munsell 7.5 YR 4/ 4 moist) ranging between 25 and $73 \mathrm{~cm}$ below the surface. This zone was mottled with whiter sand and contained a considerable amount of hematite concretions. The fifth soil zone consisted of a $15-$ to $45-\mathrm{cm}$ thick deposit of mottled reddish-yellow sand with hematite concretions (Munsell 7.5 YR 6/6 moist). It ranged from 60 to $105 \mathrm{~cm}$ below the ground surface. The sixth soil zone was a 50- to $75-\mathrm{cm}$ thick deposit of reddish-yellow sand mottled with whiter sand and containing a higher concentration of hematite concretions (Munsell 7.5 YR 6/ 6 moist). This sixth zone ranged between 89 and $145 \mathrm{~cm}$ below the ground surface and was distinguished by the inclusion of thin (1-to 2-cm thick) bands of red sandy clay (Munsell 2.5 Y R 4/8 moist). These thin bands are almost uniformly deposited at $7-8 \mathrm{~cm}$ intervals throughout the soil zone. The seventh soil zone consisted of a deposit of light pinkish-brown sand (Munsell 5 YR 7/4 moist) of an undetermined thickness ranging between 145 and $154 \mathrm{~cm}$ below the surface, corresponding to the bottom of the trench. This zone was considerably lighter in color than the previous zones.

The stratigraphy established from the profile of Gradall Trench 3 is representative of the natural stratigraphy at the site. However, two further stratigraphic distinctions were observed. The first observation was made in the central area of the site near centerline station $200+00$ where the most extensive removal of sand had occurred. In this area, the stratum corresponding to zone VII in Gradall Trench 3 (described above) was observed in the pit profile continuing to approximately another meter in depth. This pinkish zone in the central area was also ribboned with the thin bands of reddish-brown clay that were present in the sixth zone of Gradall Trench 3. Below the pinkish zone in the central area were deposits of dense orange-red clay resting on patches of sandstone.

The second observation was made in Gradall Trench 11, a shallow trench located near centerline station $197+00$ in the extreme northern end of the site. Trench 11 , which reached a maximum depth of $55 \mathrm{~cm}$ below the ground surface and an average depth of $30 \mathrm{~cm}$, clearly revealed a lack of intact topsoils. The remaining stratigraphy, however, indicated that the soils in this area were much shallower than in the remainder of the site. Trench 11 contained three distinct soil zones (Fig. 4). 

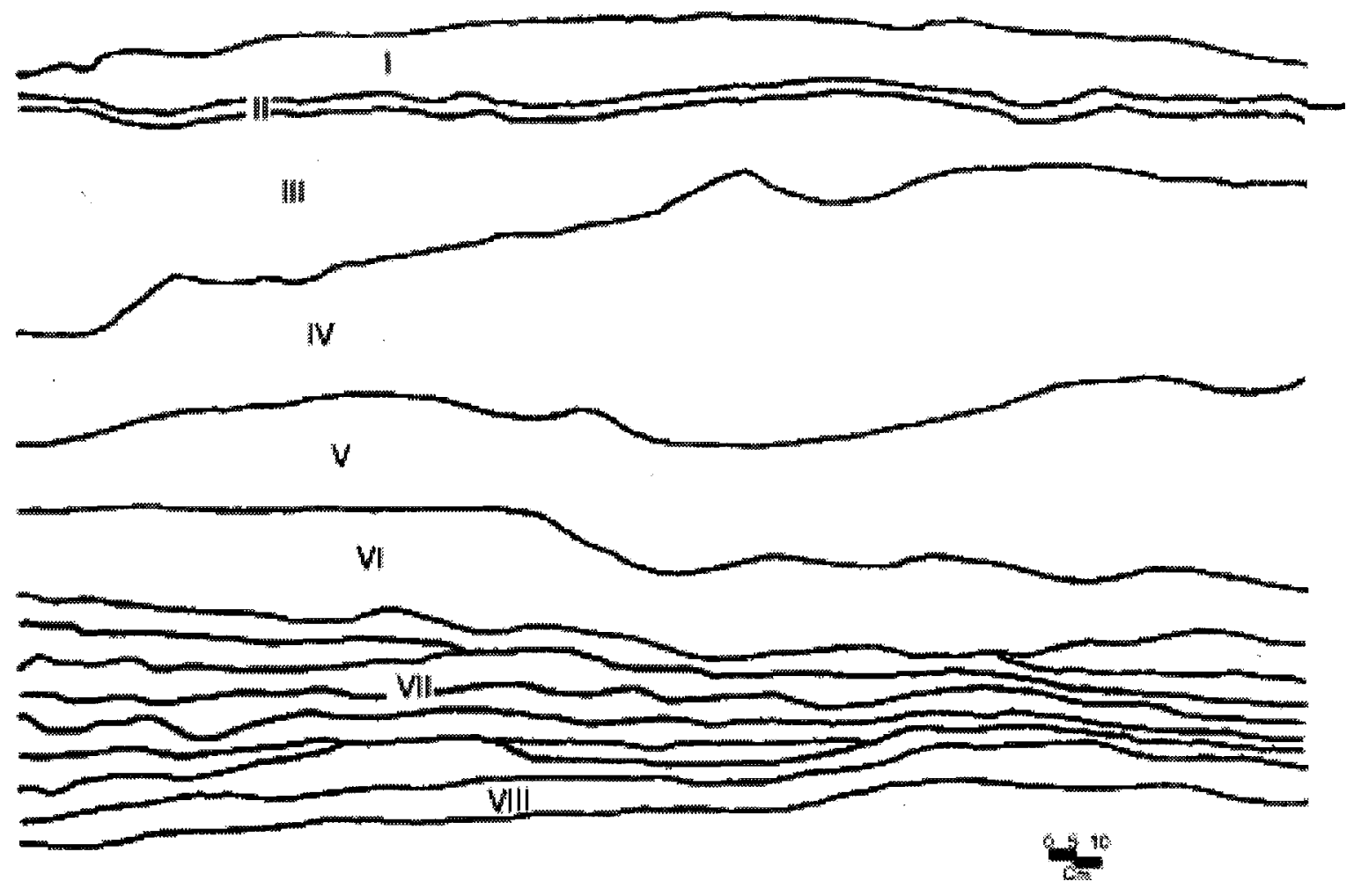

I. 10YR4/4 dark yellowish-brown sandy loam with grass roots

II. 10YR7/2 light gray sand lens

III. 7.5YR4/4 dark brown sand with iron nodules and roots

IV. 7.5YR4.6strong brown sand with white mottling iron nodules and fewer roots

V. 7.5YR6/6 reddish-yellow sand with white mottling iron nodules and roots

VI. 7.5YR4/8reddish-yellow sand with more white mottling than previous level

VII. 2.5YR4/8 red sandy clay lenses sandwiched between layers of level VI.

VIII. 5YR7/4 pink sand

Figure 3. Profile of a portion of the east wall of Gradall Trench 3. 
Because of the sloping, artificially-created ground surface, the upper two zones both begin at the surface, but at different elevations. The uppermost zone consisted of a brown sand (Munsell 10 Y R 7/2 graybrown) extending from the ground surface to a depth of $35 \mathrm{~cm}$. The second soil zone in Trench 11 consisted of a yellow-brown sand (Munsell 10 Y R 4/4) extending from the ground surface to a depth of $45 \mathrm{~cm}$. This zone extended below the upper zone and was mottled with both the matrix of the upper zone and orange-red clay of the third zone below. The third zone encountered at the bottom of the trench at 45 to $55 \mathrm{~cm}$ below the ground surface consisted of a very dense orange-red sandy clay (Munsell 2.5 Y R 6/6).

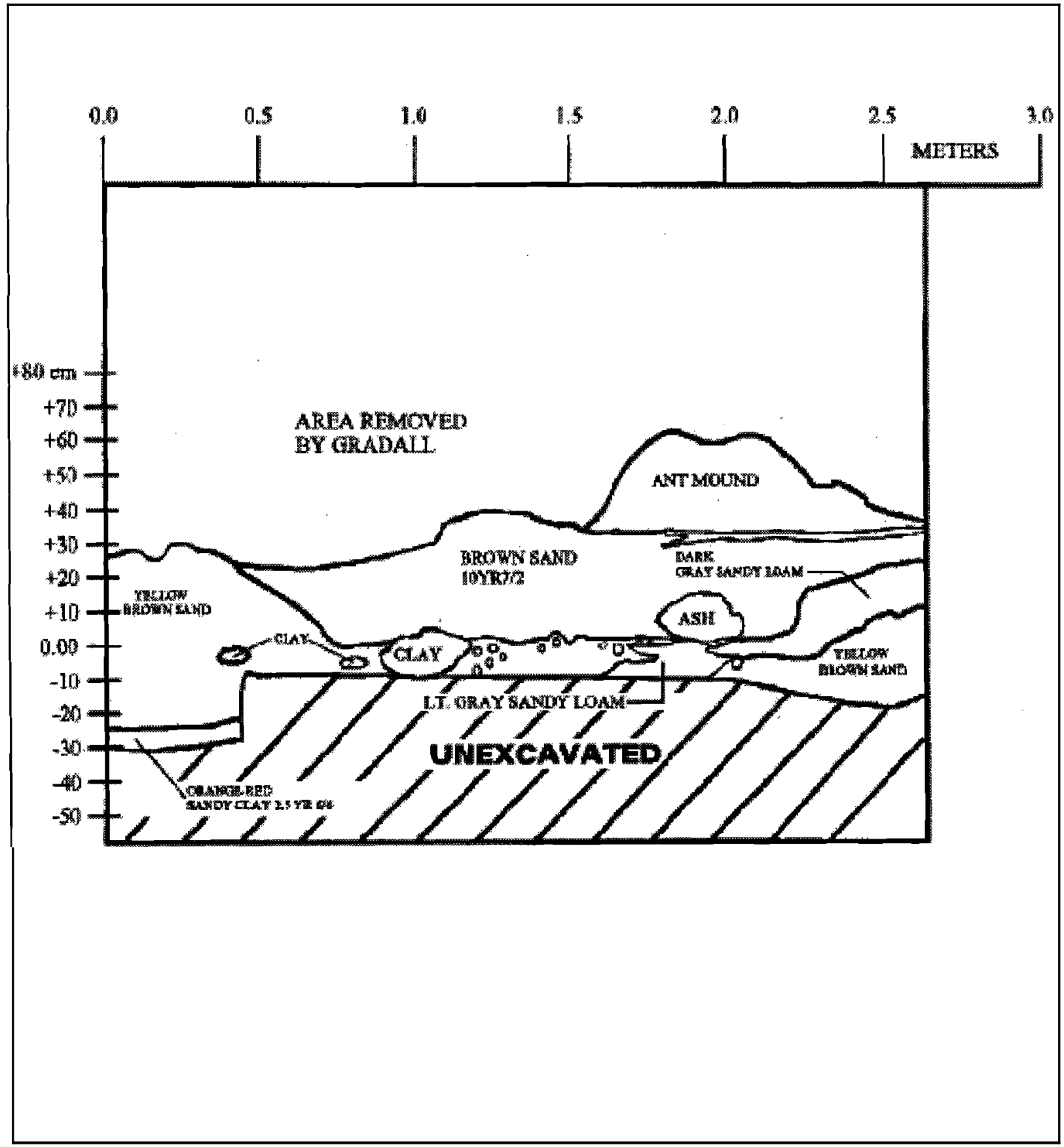

Figure 4. Profile of the west wall of Gradall Trench 3. 


\section{The Artifact Assemblage}

The test excavation of 41RK195 produced a total of 85 aboriginal artifacts and three historic artifacts (Table 1). Of this number, more than half $(n=47)$ were collected from the surface, five came from the 50x50 cm shovel tests, and the remainder, only 36 specimens, came from the $1 \times 1 \mathrm{~m}$ test pits. Of the test pits, only one, TP 5 , produced more than six artifacts. With 17 flakes and a single sherd, TP 5 accounted for almost half of the excavated artifact total; however, with 17 levels, TP 5 averaged only one artifact per $10 \mathrm{~cm}$ level. Level 15 , with four flakes, was the only one with more than two artifacts. No artifacts were found in the deepest two levels $(150-170 \mathrm{~cm})$.

Dividing the 85 prehistoric artifacts into tool and debitage categories, there are 73 pieces of debitage, three ceramic sherds, two complete dart points, one fragmentary dart point, two biface fragments, one arrowpoint, one core remnant, two mano fragments, and three sherds of historic ceramics. Other materials recovered consist of 9 fragments of nutshell and 10 small fragments of bone.

\section{Lithic Debitage}

\section{ANALYsis}

A reflection of the destroyed condition of the site, the debitage sample consists of only 73 specimens of various siliceous materials (from a site such as this the sample should have been in the hundreds, if not thousands). Making up this sample are at least 10 varieties of more or less distinctive lithic materials (mainly cherts and flints). Only two of these material types are represented by more than seven specimens. The most numerous variety, tan chert, has 24 specimens. This category is a catchall for various light brown or tan flakes of flint and chert. It is possible that several sources are represented in this sample, most likely gravels of the region or from drainages to the west such as those of the Neches and Trinity rivers.

Next in frequency with 17 specimens is a mixed category designated gray-tan speckled chert. The color range of this group is medium gray to light brown, with all specimens having small white specks. This material is very similar to good-quality stone from the northeastern section of the Edwards Plateau, in the region of Coryell County, but it might also occur at places between there and Rusk County. One such area might be the vicinity of the Jewett Mine Project (Fields 1990) in Leon County, which is an area of fairly abundant
Uvalde Gravels. There, it was found that approximately 47 percent of the debitage was of non-local origin. A fair amount of this material is similar to the various chert found in Bell, Coryell, and McLennan counties. At least one cache of flint (heat-treated bifacial blanks) from this region, believed to be from the Leona Park vicinity of Lake Belton in Bell County, has been found in east Texas [Texas Archeological Research Laboratory (TARL) collectionsl, apparently from an Archaic context at the George C. Davis Site (41CE19) in Cherokee County. This site is southwest of Rusk County and not far from the present project. Also found at the Davis Site, as grave goods of the Caddoan era, were Gahagan bifaces made of central Texas flints. Based in part on evidence such as this, it appears that lithic materials from sources along the eastern margin of the Edward Plateau were brought into east Texas over thousands of years. Some of these sources seem to be represented at 41RK195 in the form of two late Paleoindian points and a Calf Creek (Andice) point of Georgetown flint.

Good-quality raw material and blanks, especially novaculite, also came into east Texas from the north and northeast, from sources such as gravels of Red River and primary sources in Oklahoma and Arkansas. The fact that only two flakes and one dart point (Gary) of novaculite are in the present sample is at least partly a reflection of the distance from those sources to Rusk County. Although sparse, these novaculite specimens verify the expected link to resources of the north and northeast; some less distinctive pieces may also be from northern sources. Thus, it is again apparent, as it is at most substantial sites of east-northeast Texas, that many materials from distant sources were necessary to sustain the regional knapped stone industry.

Next in frequency among the debitage is a miscellaneous category of 11 specimens. Some of these, mainly translucent pieces of unusual color, may be of non-local origin. The next largest variety, with seven flakes, is Ogallala fine-grained quartzite, often called Potters chert. This is a local material that is often the major stone at east Texas sites north and northwest of Rusk County. Following quartzite, the red chert (some of silicified claystone) category has only five pieces, then the dark brown-yellow has three, the tan-yellow has two, the white has three, and there are two pieces of silicified wood. As noted above, there are two flakes -- one white, one pink-- that appear to be novaculite. The remainder of the debitage $(n=12)$ is of unknown origin.

The small size of the lithic artifact sample precludes a thorough understanding of tool manufacture and use at 41RK195. However, from a brief analysis of the 
debitage it has nevertheless been possible to gain some insight into manufacturing processes and tool use at 41RK195, as well as into the size and origin of raw materials. To accomplish this, the debitage was separated into the following categories: 1) soft-hammer method, 2) hard-hammer method, and 3) fragment. Of the 73 flakes and fragments. 43 retain the platform that is critical to discerning manufacturing methods; the remaining 30 specimens are medial and distal fragments. Of the 43 platforms, 3 specimens have characteristics of hard-hammer percussion and 40 have characteristics of soft-hammer percussion. At this point, it should be noted that certain of these specimens could have been produced by other methods such as pressure flaking. In this sample, this might apply to a few of the smallest flakes classified as soft hammer, since characteristics of the various methods often overlap (most pressure flake fragments would not have been caught by the 1/4-in. screen). For this reason, it is probably more appropriate not to use precise figures, but the soft hammer method was clearly dominant in the available sample, apparently accounting for 90 percent or more of the total.

Another important variable when considering the origins of raw material and reduction strategies is the percentage of cortex in the sample, which is quantified in the following manner: primary cortex - $100 \%$, secondary cortex $-1-99 \%$, tertiary - 0\% cortex. The assemblage from 41RK195 has three primary flakes (4\%), 17 secondary flakes (23\%), and 53 tertiary flakes $(73 \%)$. Thus, only $27 \%$ of the sample has cortex.

Also significant is the size of the debitage. Only one of the 73 flakes is larger than $40 \mathrm{~mm}$. Of the rest, 21 (28\%) range from $20-40 \mathrm{~mm}$, and $51(70 \%)$ are smaller than $20 \mathrm{~mm}$. Roughly half of the specimens with platforms are complete.

\section{Conclusions}

After combining these data with the observations on material types, a few conclusions about the knapped stone industry at 41RK195 are possible. However, such a small sample is most likely not representative of the site as a whole nor of any of its cultural components, but it can nevertheless be compared to certain trends known for the region.

First, Rusk County lies in a region that is generally poor in lithic (knapping) resources, both in quantity and size. Therefore, it is not surprising that the debitage sample is of small average size. It is also not unusual in this region for the total debitage sample to be on the small side, but too little of the site remained to consider this variable.

In regions poor in raw material, there is frequently a significant amount of imported lithic resources that arrived in a partially or almost completely reduced state. The further working of such material often results in low frequencies of hard hammer flakes, cortex flakes, and large flakes. These conditions all exist in the present sample but, again, these data are of questionable reliability due to the sample's small size. There can be no doubt, however, that the small, mostly tertiary, softhammer flakes found are the product of final stage thinning, sharpening, and resharpening of bifaces the size of dart points. It is very likely that some bifaces were brought to this site in the form of blanks and were then turned into finished tools, while others were refurbished at the site.

It appears that at least half of the flake debitage is material of non-local origin, with some probably coming from the larger drainages to the west and some possibly from as far away as the northeastern margin of the Edwards Plateau. Other materials likely originated in or were washed from the mountains of Oklahoma and Arkansas, or places even farther away. 


\section{Artifact Description}

\section{BIFACES}

Though numbering only five, the sample of diagnostic bifaces and fragments is large relative to the debitage sample. Of the five specimens, two can be readily identified as Gary points, although they are missing parts of the stems. These points are considerably different and reflect some of the variation within the Gary type, variation which may have temporal significance. One (Fig. 5A) is large $(\mathrm{L}=61+\mathrm{mm} ; \mathrm{W}=34$ $\mathrm{mm}$; Thk $=9 \mathrm{~mm}$ ), thick and has a stem that gradually contracts away from the shoulders. Broken by a straight snap, the stem now accounts for only $15 \mathrm{~mm}$ of the total length. At the time of breakage, it probably amounted to about 40 percent of the total length. Originally, however, it would have amounted to less because the blade, with recurved edges and a slight alternate bevel, is clearly narrower and shorter than when freshly made. It is made of white novaculite possibly from Arkansas.

The second Gary point (Fig. 5B), also broken in the stem, is small $(\mathrm{L}=28 \mathrm{~mm} ; \mathrm{W}=25 \mathrm{~mm}$; Thk $=5.5 \mathrm{~mm})$, thin, and made of yellowish brown/olive fine-grained quartzite. The stem remnant is almost straight below wide-flaring, straight shoulders. Before breakage, the stem, now 7-mm long, possibly accounted for as much as 40 percent of the total length. The blade is a small equilateral triangle that also shows signs of having been reworked, including being a little asymmetrical. Both Gary points were surface finds.

The third bifacial specimen (Fig. 5C) is a fragment of a small dart point that possibly had a contracting stem typical of the Gary type. Made of yellowish-brown local chert, it appears to be broken at the shoulder and is 6-mm thick.

The last specimen of the dart point group is a small distal tip. Only $12-\mathrm{mm}$ long and 4-mm thick, it is made of a lustrous pale brown flint of unknown origin.

The fifth biface is the only arrowpoint (Fig. 5D) recovered during the test excavation. Its stem, 6-mm long and 5-mm wide, expands slightly and is the only part that is not broken. Made of olive brown to red local chert, this fragment might have been a Friley point. It is just under 4-mm thick.

In this small collection, there are only two other specimens that were intentionally shaped, or knapped. The smaller one (Fig. 5E) is a bifacially worked object that might be a remnant of a slightly larger biface or a thoroughly reduced pebble. It is a multicolored brown local chert that retains a bit of cortex. It is $23-\mathrm{mm}$ long and 9-mm thick. The last knapped object is a small core fragment (Fig. 5F) of reddish brown Ogallala quartzite. It retains cortex over much of one surface, its inside surfaces looking as if they had been pulverized instead of knapped. This fragment is a candidate for the hammer/ anvil (bipolar) technique of hard-hammer percussion.

A much better understanding of the range of human habitation at 41RK195 than is possible from the small assemblage just described comes from the artifact collections of local individuals. Although this amounts to only five specimens, four of them are from the earlier Archaic periods or the late Paleoindian era. The two most notable pieces are basal sections that bear certain similarities to two types from different parts of the state: the Golondrina type of central and southwest Texas, and the Dalton type found in this region. The other two identifiable specimens are of the Wells and Calf Creek (Andice) types.

\section{Ceramics}

Only three prehistoric potsherds, each from a different Caddoan vessel, were recovered at 41RK195. The largest of these (Fig. 5G) has an exterior surface that is totally covered with fingernail punctations. Grog tempered, its exterior surface ranges from light brown to dark grayish brown; the smoothed interior is dark gray. Thickness is $6 \mathrm{~mm}$.

The second sherd, of light yellowish brown color, is plain and only roughly smoothed on both surfaces. Also grog tempered, it is almost 8-mm thick.

The last sherd (Fig. 5H) is from the rim of a thinwalled vessel. Its interior is a light yellowish gray to brown color; the exterior is dark gray and has three fine horizontal incised lines that are 4-mm apart. This specimen has an everted rim and a flat lip. It has bone temperin a paste of dark gray color. Maximum thickness is $5 \mathrm{~mm}$. Though not identifiable, the decorated sherds are probably from the Early or Middle Caddoan periods.

A total of three historic sherds were also collected during test excavations. These specimens appear to be from three different whiteware vessels

\section{Ground Stone}

The two ground stone tools from 41RK195 are made of hard ferriginous sandstone. One is a fragment of a single facet mano that probably had an oblong shape. Expanding at the point of breakage, the original 
specimen was wider than the $51 \mathrm{~mm}$ that remains; maximum thickness is $36 \mathrm{~mm}$ and weight is $129 \mathrm{gm}$.

The second specimen (Fig. $5 l$ ) is complete and appears to have been a multiple-use tool of some kind. Its subrectangular shape was created by knapping around its entire perimeter; its dimensions are: $L=77 \mathrm{~mm}$, $\mathrm{W}=54 \mathrm{~mm}$, Thk $=19 \mathrm{~mm}$, and its weight is $149 \mathrm{gms}$. At one end, the ventral surface is flat. Toward the middle, it becomes convex and becomes more so as it curves up to the bit at the opposite end. Almost half of the apparent bit is broken away, and the remaining edge shows some wear, but it is not pronounced. Much of the two lateral edges show heavier wear or smoothing. The proximal end is rougher and only one comer of the edge is rounded. The ventral surface is relatively smooth and may have been used in mano fashion, but it is not nearly as smooth as the one described above. The primary function of this specimen evidently was as an adze. 


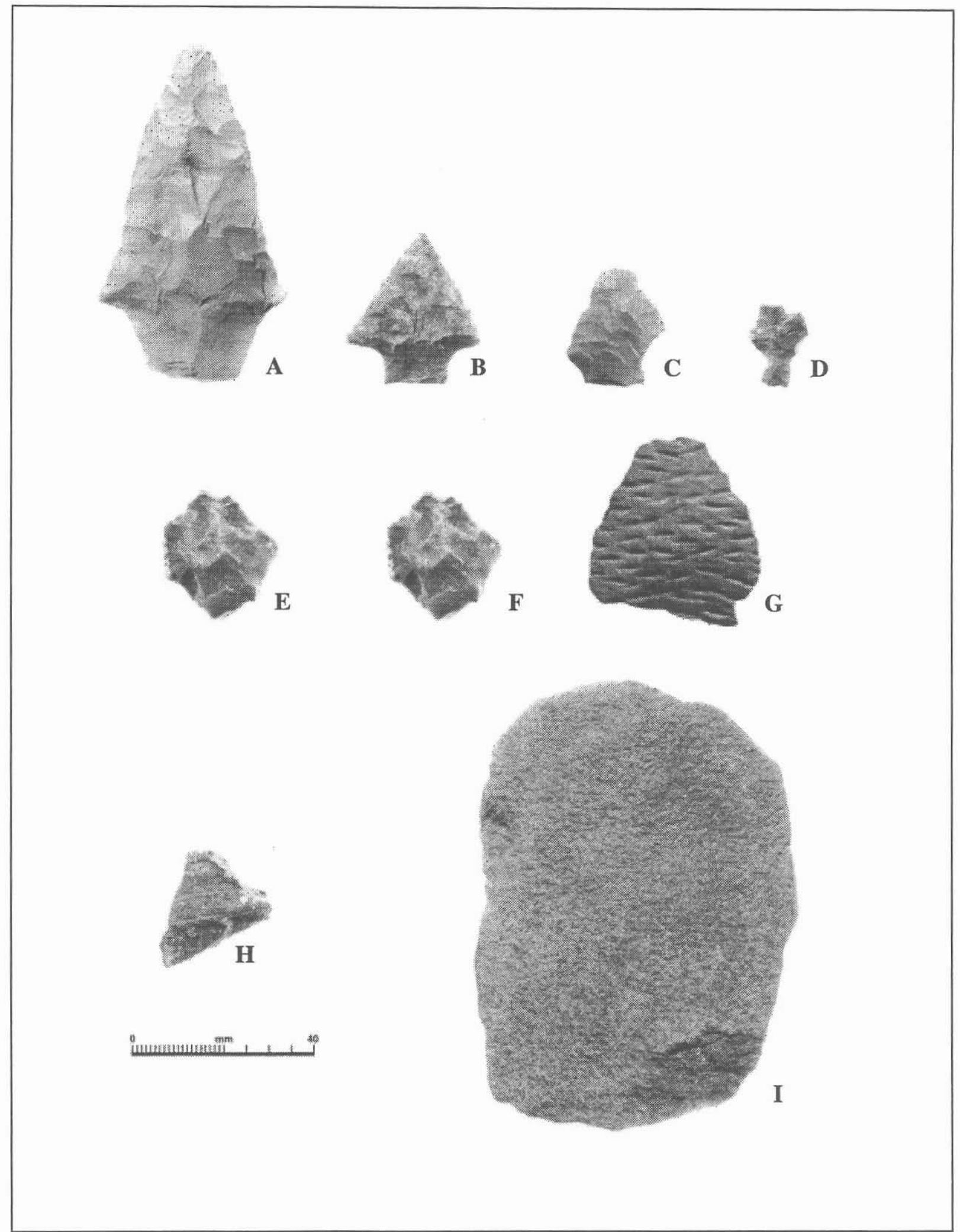

Figure 5. Selected lithic and ceramic artifacts from sitee 41RK 195. 


\section{Summary AND Recommendations}

The brief but thorough program of test excavation implemented at Site 41RK195 has provided sufficient data for making NRHP and State Archeological Landmark (SAL) determinations. It is believed that the comparatively large number of excavation units shovel tests, test pits, Gradall trenches - was more than adequate to sample the remnants of this site, particularly since these remnants amount to only a small percentage of the original site area.

In the mid-1970s, the landowner, Mr. Aubrey Layne, turned this once prominent hill into a sand quarry, and since that time has removed at least half of it. Along with the sand, as it turns out, there was also removed a great majority of the aboriginal habitation debris that had accumulated over perhaps as much as nine or ten thousand years. In some places, more than $7 \mathrm{~m}$ of sand were quarried, while in others, only the upper 1-3 m were taken. However, this was done so thoroughly that almost the entire aboriginal site was removed or seriously disturbed.

From what was learned during the TxDOT excavations, as well as from local artifact collectors, it is believed that 41RK195 was a multi-component site that was used during the Paleoindian, Archaic, and Caddoan periods. Of the many artifacts that had been collected prior to the test excavation, only five dart points were available for examination. These specimens are the basis for claiming late Paleoindian and various Archaic occupations of the hill. Most likely, the hill was also visited during the Early Ceramic Period, the grogtempered sherd and a Gary point possibly being from this time.

Though only meager evidence remains at Site 41RK195, when coupled with previously collected materials it helps make a case for the site having been an aboriginal habitation area of considerable significance. The hill was of such large size and favorable location as to be attractive to peoples throughout time, and, in addition to being a habitation site, it most likely received various human interments through the millenia. Within the Historic era, the hill possibly was the location of a farmstead, given the presence of ceramics and non-native vegetation such as crepe myrtle. The cultivation that continued into recent years possibly began early in the 20th century, if not earlier.

Within the proposed TxDOT right of way there remains only the smallest sample of cultural material, and east of the right of way there appears to be very little more that is not disturbed. Therefore, the only recommendation possible is that the remnant of Site 41RK195 is not now eligible for NRHP and SHL designation, and no further investigation is warranted. 


\section{References Cited}

Arbingast, S.A., L.G. Kennamer, R.H. Ryan, A. Lo, D.L. Karney, C.P. Zlatkovich, M.E. Bonine, and R.G. Steele

1973 Atlas of Texas. Bureau of Business Research, The University of Texas at Austin.

Barnes, Virgil E.

1965 Geologic Atlas of Texas, Tyler Sheet. The University of Texas, Bureau of Economic Geology. Austin.

Blair, W.F.

1950 The Biotic Provinces of Texas. Texas Journal of Science 2:93-117.

Burt, William H., and Richard P. Grossenheider 1976 A Field Guide to the Mammals, Third Edition. The Peterson Field Guide Series, No. 5. Houghton Mifflin Co., Boston.

Carr, J.T.

1967 The Climate and Physiography of Texas. Report 53. Texas Water Development Board, Austin.

Clark, J.W., and J.E. Ivey

1974 Archaeological and Historical Investigations at Martin Lake, Rusk and Panola Counties, Texas. Research Report 32. Texas Archeology Survey, The University of Texas at Austin.

Cruse, J. Brett

1994 Oak Hill Mine Data Recovery at Site 41RK214. Cultural Resource Management News and Views 6(2):9-10. Texas Historical Commission. Austin.
Davis, E.M.

1970 Archaeological and Historical Assessment of the Red River Basin in Texas. In Archaeological and Historical Resources of the Red River Basin, edited by H.A. Davis, pp. 25-65. Research Series No. 1. Arkansas Archaeological Survey, Fayetteville.

Davis, William A., and E. Mott Davis 1960 The Jake Martin Site: An Archaic Site in the Ferrell's Bridge Reservoir Area, Northeastern Texas. The University of Texas at Austin, Department of Anthropology Archaeology Series 3.

Espey, Huston and Associates, Inc.

1990 Cultural Resources Investigations of the Oak Hill 2280 Acre Study Area, Rusk

County, Texas. Espey, Huston and Associates, Inc., Austin.

Fenneman, N.M.

1938 Physiography of Eastern United States. McGraw-Hill, New York.

Fields, Ross C. (Editor)

1990 Excavations at the Charles Cox, Lambs Creek Knoll, and Buffalo Branch Sites. Jewett Mine Project, Leon and Freestone Counties, Texas. Volume 1; Report of Investigations, Number 70. Prewitt and Associates, Inc., Austin.

Fisher, W.L.

1965 Rock and Mineral Resources of East Texas. Report of Investigations No. 54. Bureau of Economic Geology, The University of Texas at Austin. 
Godfrey, C.L., G.S. McKee, and H. Oakes

1973 General Soil Map of Texas. Texas Agricultural Experiment Station, Texas A\&M University, in cooperation with Soil Conservation Service, United States Department of Agriculture.

Goldschmidt, W.

1935 Some Archaeological Sites in Titus County and Their Relation to East Texas Prehistory. Master's Thesis, The University of Texas at Austin.

Gould, Frank W.

1969 Texas Plants, A Checklist and Ecological Summary. Texas Agricultural Experiment Station, Texas A\&M University, College Station.

1975 The Grasses of Texas. Texas Agricultural Experiment Station, Texas A\&M University, College Station.

Holm, Melody

1975 A Preliminary Study of Biologic Assemblages of East Texas Lignite Belt. Bureau of Economic Geology Research Note 1. The University of Texas at Austin.

House, Kurt D.

1978 Texas Archeology. Southern Methodist University Press, Dallas, Texas.

Hughes, Jack T.

1948 Untitled Notes. On file at Texas Archeological Research Laboratory, J.J. Pickle Research Campus, The University of Texas at Austin.

Jackson, Jack M.

1982 A Cultural Resource Survey in Martin Luke Area D: Intensive Survey I, Rusk County, Texas. Texas Archeological Research Report No. 85, The University of Texas at Austin.
Johnson, L., Jr.

1962 The Yarbrough and Miller Sites of Northeastern Texas, with a Preliminary Definition of the La Harpe Aspect. Bulletin of the Texas Archeological Society 32:141284.

Keller, J.E.

1974 The Subsistence Paleoecology of the Middle Neches Region of Eastern Texas. Unpublished Ph.D dissertation, Department of Anthropology, The University of Texas at Austin.

McDonald, A.J.

1972 An Archaeological Survey of the Martin Luke Area, Rusk and Panola Counties, Texas. Research Report No. 14. Texas Archeological Salvage Project, The University of Texas at Austin.

Perttula, Timothy K.. Bob D. Skiles, Michael B. Collins, Margaret C. Trachte, and Fred Valdez, Jr.

1986 "This Everlasting Sand Bed": Cultural Resources Investigations at the Texas Big Sandy Project, Wood and Upshur Counties, Texas. Reports of Investigations 52. Prewitt and Associates, Inc. Austin.

Sellards, E.H., W.S. Adkins, and F.B. Plummer 1932 The Geology of Texas. Bulletin 3232. The University of Texas at Austin.

Skinner, S. Alan

1971 Historical Archeology of the Neches Saline, Smith County, Texus. Texas Historical Survey Committee, Archeological Report No. 21. Austin.

Stebbins, Robert C.

1966 A Field Guide to Western Reptiles and Amphibians. The Peterson Field Guide Series, No. 16. Houghton-Mifflin Co., Boston. 
Story, Dee Ann, Janice A. Guy, Barbara A. Burnett, Martha Doty Freeman, Jerome C. Rose, D. Gentry

Steele, Ben W. Olive, and Karl J. Reinhard

1990 The Archeology and Bioarcheology of the Gulf Coastal Plain: Vol 1. Arkansas

Archeological Survey Research Series No. 38

Fayetteville. Submitted to the U.S.

Army Corps of Engineers, Southwestern

Division.

Story, D.A., and S. Valastro, Jr.

1977 Radiocarbon Dating and the George C. Davis Site, Texas. Journal of Field Archaeology 4:63-89.

Suhm, D.A., A.D. Krieger, and E.B. Jelks

1954 An Introductory Handbook of Texas Archeology. Bulletin of the Texas Archeological Society 25.

Thurmond, J.P.

1985 Late Caddoan Social Group Identifications and Sociopolitical Organization in the Upper Cypress Basin and Vicinity, Northeastern Texas. Bulletin of the Texas Archeological Society 54 (for 1983):185200. Austin.

Tunnell, Curtis D.

1961 Evidence of a Late Archaic Horizon at Three Sites in the McGee Bend Reservoir, San Augustine County, Texas. Bulletin of the Texas Archeological Society 30 (for 1959):123-158. Austin.

Webb, Clarence H.

1960 A Review of Northeast Texas Archeology. Bulletin of the Texas Archeological Society 29:35-62. Austin. 